ARTIKEL PENELITIAN

\title{
PENGARUH KEBERSIHAN GIGI DAN MULUT DENGAN STATUS GINGIVITIS PADA IBU HAMIL DI WILAYAH KERJA PUSKESMAS ANDALAS KECAMATAN PADANG TIMUR KOTA PADANG TAHUN 2012
}

\author{
Hidayati $^{1}$, Kuswardani ${ }^{2}$, Gustria Rahayu ${ }^{3}$ \\ 1. Staf Fakultas Kedokteran Gigi Universitas Andalas \\ 2. Staf Program Studi Psikologi Universitas Andalas \\ 3. Mahasiswa Fakultas Kedokteran Gigi Universitas Andalas \\ email : fauzanyusro@yahoo.com
}

\section{Abstrak}

Gingivitis kehamilan adalah gingivitis yang terjadi pada wanita hamil. Gingivitis disebabkan oleh iritasi bakteri yang ada dalam plak dan kalkulus. Plak dan kalkulus merupakan indikator kebersihan mulut yang buruk. Selama kehamilan, hormon estrogen dan progesterone akan mengalami peningkatan yang menyebabkan jaringan gingiva merespon secara berlebihan terhadap iritasi lokal. Penelitian ini bertujuan untuk mengetahui tingkat kebersihan rongga mulut dan status gingivitis ibu hamil serta hubungan antara tingkat kebersihan rongga mulut dengan status gingivitis pada ibu hamil. Jenis penelitian ini adalah anayitic correlation dengan pendekatan cross sectional, sampel diambil menggunakanteknik accidental sampling dengan uji statistik Kolmogorov-Smirnov. Subjek adalah 70 wanita hamil di Puskesmas wilayah kerja Andalas Padang Timur. Hasil penelitian menunjukkan tingkat kebersihan mulut ibu hamil di wilayah kerja Puskesmas Andalas Kecamatan Padang Timur sebagian besar adalah sedang $(57,1 \%)$ dan sebagian besar ibu hamil yang diperiksa mengalami gingivitis sedang (70\%). Semua ibu yang diperiksa mengalami gingivitis, baik itu ibu dengan tingkat kebersihan mulut yang baik, sedang maupun buruk. Disarankan kepada ibu hamil untuk selalu menjaga kebersihan dan kesehatan rongga mulutnya.

Kata Kunci : gingivitis kehamilan, estrogen, progesteron, tingkat kebersihan rongga mulut, gingivitis

\section{Abstract}

Pregnancy gingivitis is gingivitis that occurs in pregnant women. Gingivitis caused by the irritation of bacteria in plaque and calculus. Plaque and calculus is indicator of poor oral hygiene. During pregnancy, estrogen and progesterone will increase that causes excessive gingival tissue response to local irritation. This study aims to determine oral hygiene level and gingivitis status in pregnant women and relationship between oral hygiene level with gingivitis status in pregnant women. The kind of this research is analyitic correlation with cross sectional study, samples were taken with accidental sampling technique with statistical test Kolmogorov-Smirnov. Subject were 70 pregnant women at the work area Puskesmas Andalas Padang Timur. The results showed oral hygiene level in pregnant women at the work area Puskesmas Andalas Padang Timur are mostly moderate (57.1\%) and majority of them had moderate gingivitis (70\%). 
All of the pregnant women were examined had gingivitis, both pregnant women with good oral hygiene, medium and bad. It is recommended to pregnant women to always maintain the hygiene and health of the oral cavity.

Key word : pregnancy gingivtis, estrogene, progesterone, oral hygiene and gingivitis. 


\section{Pendahuluan}

Kehamilan merupakan suatu peristiwa yang sering dijumpai dalam kehidupan seorang wanita, $^{(1)}$ yang merupakan keadaan fisiologis yang diikuti perubahan hormonal, dimana tidak hanya mempengaruhi kesehatan umum tetapi juga kesehatan gigi dan mulut. ${ }^{(2)}$ Peningkatan resiko terjadinya penyakit mulut pada wanita hamil dapat disebabkan oleh beberapa faktor seperti refleks muntah (gagging), nausea dan muntah yang dapat meningkatkan resiko terjadinya karies gigi, rasa takut menggosok gigi karena keadaan gingiva yang dapat meradang pada masa kehamilan, bahkan perubahan perilaku atau kebiasaan seperti mengabaikan kebersihan rongga mulut yang dapat meningkatkan frekuensi karies dan penyakit periodontal. ${ }^{(3)}$

Gingivitis adalah sebuah reaksi inflamasi dari gingival yang disebabkan oleh akumulasi biofilm pada plak di sepanjang gingival margin dan respon host inflamasi terhadap produk bakteri. Gejala klinis gingivitis ditandai dengan adanya perubahan warna, perubahan bentuk, perubahan konsistensi (kekenyalan), perubahan tekstur, dan perdarahan pada gusi. ${ }^{(4)}$

Kehamilan dapat memperberat gingivitis yang biasa dikenal dengan pregnancy gingivitis atau radang gusi selama kehamilan, ${ }^{(5)}$ yang merupakan respon inflamasi yang berlebih dari gingiva terhadap dental plak dan perubahan hormonal yang biasa terjadi selama masa kehamilan. Gejala klinis gingivitis ini mulai terlihat sejak bulan kedua dari kehamilan dan mencapai puncak pada bulan kedelapan. ${ }^{(4)}$ Peningkatan hormon seksual terutama hormon progesteron dan estrogen pada masa kehamilan dapat menimbulkan perubahan pada rongga mulut berupa meningkatnya permeabilitas pembuluh darah gingiva sehingga menjadi sangat peka terhadap iritasi lokal seperti plak, kalkulus dan karies. ${ }^{(6)}$

Beberapa studi yang dikutip dari Diana (2010) menyatakan bahwa efek perubahan hormonal akan mempengaruhi kesehatan gigi wanita hamil sebesar $60 \%$ dimana 10\%-27\% mengalami pembengkakan gusi. ${ }^{(3)}$ Persatuan Dokter Gigi Indonesia (PDGI) yang dikutip dari Hartati dkk (2011) juga mencatat radang gusi merupakan masalah gigi dan mulut yang sering dijumpai pada ibu hamil dimana 5\%$10 \%$ nya mengalami pembengkakan gusi. $^{(7)}$

Penelitian yang dilakukan oleh Retroningrum (2006) menyatakan gingivitis dan status gizi pada ibu hamil berhubungan secara bermakna dan merupakan faktor risiko terjadinya bayi berat badan lahir rendah (BBLR) kurang bulan. ${ }^{(5)}$ Hal tersebut diperkuat oleh Republika Newsroom pada tahun 2009 yang dikutip dari Hartati dkk (2011) menerbitkan tentang Survei Kesehatan Nasional tahun 2002 yang menyebutkan bahwa $77 \%$ dari ibu hamil yang menderita radang gusi melahirkan bayi secara premature. ${ }^{(7)}$ Hasil riset Academy of General Dentistry yang dikutip dari Novianto (2010) juga menunjukkan, ibu hamil yang menderita infeksi gusi memiliki kemungkinan 6 kali lebih tinggi untuk melahirkan bayi premature dan bayi lahir dengan berat badan rendah. ${ }^{(8)}$

Selain masalah hormonal, penyebab utama gingivitis saat hamil adalah buruknya kebersihan mulut yang memudahkan terjadinya iritasi pada gingiva oleh enzim dan toksin bakteri anaerob yang terkandung dalam plak. ${ }^{(9)}$ Penelitian yang dilakukan Wardhani (2012) menunjukkan adanya hubungan antara tingkat kebersihan mulut ibu hamil dengan status gingivanya yaitu semakin buruk tingkat kebersihan mulut ibu hamil maka semakin buruk juga 
status gingivanya. ${ }^{(10)} \mathrm{Hal}$ ini didukung oleh penelitian yang dilakukan oleh Hartati dkk (2011) yang mendapatkan ibu hamil dengan plak pada giginya lebih banyak mengalami gingivitis dibanding ibu dengan tidak ada plak pada giginya. ${ }^{(7)}$ Penelitian yang dilakukan oleh Rintoko (2005) juga menyatakan tingkat kebersihan mulut mempengaruhi terjadinya gingivitis pada ibu hamil. ${ }^{(11)}$

Keparahan gingivitis memuncak pada usia kehamilan 8 bulan dan menurun pada usia kehamilan 9 bulan, dengan pola akumulasi plak yang sama. Beberapa peneliti melaporkan tingkat keparahan gingivitis terbesar terjadi pada trimester kedua dan ketiga. Pengurangan tingkat keparahan gingivitis dapat terjadi setelah 2 bulan paska melahirkan dan setelah satu tahun kondisi gingiva dapat kembali normal, dapat dibandingkan dengan kondisi wanita yang tidak hamil. Namun, gingiva tidak akan kembali normal jika faktor lokal tidak dihilangkan. ${ }^{(12)}$

Jadi, kehamilan itu sendiri bukanlah menjadi penyebab langsung dari gingivitis yang terjadi selama masa kehamilan, tetapi juga tergantung pada tingkat kebersihan mulut pasien. ${ }^{(6)}$ Gingivitis pada masa kehamilan disebabkan oleh bakteri plak, sama halnya seperti pada wanita yang tidak hamil. Hanya saja kehamilan dapat meningkatkan respon gingiva terhadap plak. ${ }^{(12)}$

Data dari Dinas Kesehatan Kota Padang menunjukkan, penyakit periodontitis (termasuk gingivitis) menempati urutan kedua dari 10 penyakit terbanyak di kota Padang dengan jumlah penderita tahun 2009 adlah 22.210 jiwa (Dinkes Kota Padang, 2010). Setelah dilakukan studi pendahuluan pada ibu hamil yang berkunjung melakukan pemeriksaan ke poliklinik KIA Ibu di Puskesmas Andalas Kecamatan Padang Timur, dari 10 orang ibu hamil yang dilakukan pemeriksaan kebersihan mulut dan pemeriksaan status gingivitis, didapatkan 3 ibu memiliki oral hygiene $(\mathrm{OH})$ yang baik dengan status gingivitis ringan, $5 \mathrm{ibu}$ hamil dengan $\mathrm{OH}$ sedang dengan status gingivitis sedang dan 2 ibu hamil mempunyai $\mathrm{OH}$ yang buruk mengalami gingivitis berat.

Berdasarkan hal tersebut peneliti ingin melakukan penelitian mengenai hubungan tingkat kebersihan rongga mulut dengan status gingivitis pada ibu hamil. Hasil penelitian ini diharapkan dapat memberikan informasi kepada masyarakat khususnya ibu hamil tentang pentingnya menjaga kebersihan dan kesehatan gigi dan mulut selama kehamilan sehingga timbul kesadaran untuk selalu menjaga kebersihan gigi dan rongga mulutnya.

\section{METODE PENELITIAN}

Penelitian ini dilakukan di bagian Poliklinik Gigi dan Mulut Puskesmas Andalas Kecamatan Padang Timur, Kota Padang, Provinsi Sumatera Barat. Kajian dalam penelitian ini adalah mengetahui hubungan antara tingkat kebersihan rongga mulut dengan status gingivitis pada ibu hamil. Jenis penelitian yang digunakan adalah analytic correlation dengan menggunakan pendekatan cross sectional. Jumlah sampel sebanyak $70 \mathrm{ibu}$ hamil yang diambil menggunakan metode accidental sampling.

\section{Data Primer}

Data yang dikumpulkan meliputi hasil pengukuran tingkat kebersihan gigi dan mulut ibu hamil yang kemudian dikode sesuai dengan indeks Oral Hygiene Index Simplifield (OHI-S) menurut Greene dan 
Vermilion serta hasil pengukuran tahun. Sampel terbanyak berusia 30 indeks gingiva ibu hamil yang tahun sebanyak 9 orang.

kemudian dikode sesuai dengan Indeks Diagram 1 Distribusi karakteristik Gingiva dari Loe dan Sillness sehingga responden berdasarkan usia kehamilan ibu didapatkan hasil pengukuran status gingivitis.

\section{Data Sekunder}

Hasil pendataan Dinas

Kesehatan Kota Padang tentang cakupan kunjungan ibu hamil yang berkunjung melakukan pemeriksaan kehamilan pada program KIA di Puskesmas Andalas Kecamatan Padang Timur.

\section{Analisa Data}

1. Analisa Univariat

Analisa univariat bertujuan untuk melihat distribusi frekuensi setiap variabel penelitian yaitu variabel independen (tingkat kebersihan gigi dan mulut pada ibu hamil) dan variabel dependen (status gingivitis). Data disajikan secara deskriptif dalam bentuk tabel distribusi frekuensi.

2. Analisa Bivariat

Untuk melihat hubungan tingkat kebersihan gigi dan mulut ibu hamil dengan status gingivitis selama masa kehamilan dengan menggunakan uji KolmogorovSmirnov. Taraf signifikan yang digunakan adalah 95\% dengan nilai kemaknaan $5 \% \quad(p<0,05)$ yang artinya Ho ditolak atau menunjukkan hubungan yang signifikan.

\section{HASIL PENELITIAN \\ Karakteristik Responden}

dasarkan karakteristik usia pada penelitian ini diketahui 70 responden dengan rentang usia 19 tahun sampai 43

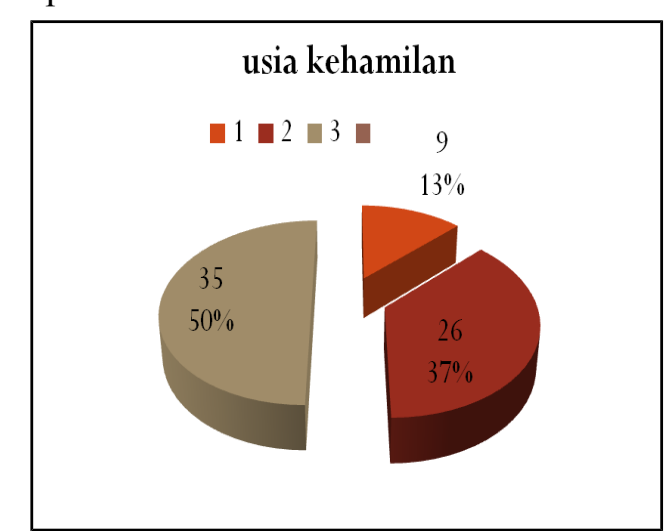

Dari diagram 1 diketahui responden terbanyak dengan usia kehamilan trimester 3 yaitu $50 \%$. Responden dengan usia kehamilan trimester 2 sebanyak $37 \%$ dan trimester 1 sebanyak $13 \%$.

\section{I.1 Tingkat Kebersihan Mulut Ibu Hamil}

Diagram 2 Distribusi frekuensi tingkat kebersihan mulut ibu hamil

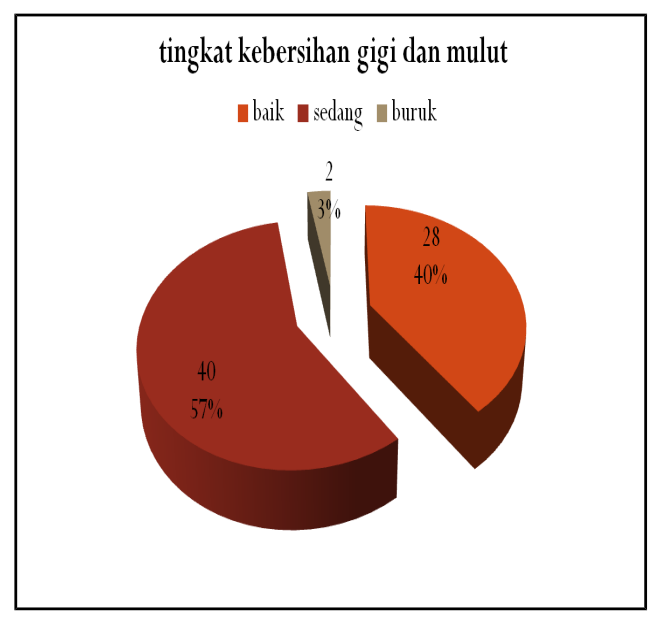

Dari diagram 2 diketahui bahwa sebagian besar ibu mempunyai tingkat kebersihan gigi dan mulut yang sedang yaitu $57,1 \%$. Hanya sebagian kecil ibu yaitu $2,9 \%$ mempunyai tingkat kebersihan gigi dan mulut buruk. Sisanya sebanyak $40 \%$ mempunyai tingkat kebersihan gigi dan mulut yang baik. 


\section{I.2 Status Gingivitis Ibu Hamil}

Diagram 3 Distribusi frekuensi status gingivitis ibu hamil

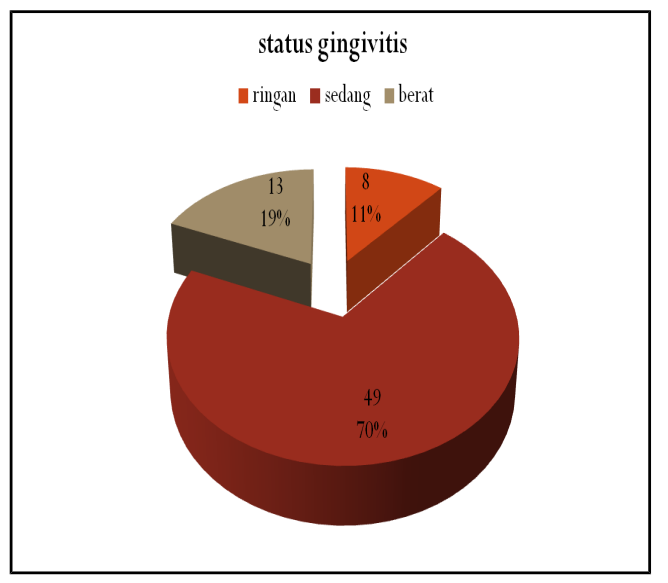

Dari diagram 3 diketahui sebagian besar ibu hamil mengalami gingivitis sedang yaitu sebanyak 70\%. \%). Sebanyak $18,6 \%$ mengalami gingivitis berat dan sisanya sebanyak $11,4 \%$ mengalami gingivitis ringan.

\section{I.3 Hubungan \\ Kebersihan Mulut dengan Status Gingivitis Ibu Hamil}

Tabel 1 Hubungan tingkat kebersihan gigi dan mulut dengan status gingivitis ibu hamil

\begin{tabular}{|c|c|c|c|c|c|c|c|c|}
\hline \multirow{3}{*}{$\begin{array}{l}\text { tingkat } \\
\text { kebersih } \\
\text { an mulut }\end{array}$} & \multicolumn{6}{|c|}{ status gingivitis } & \multicolumn{2}{|c|}{ Jumlah } \\
\hline & \multicolumn{2}{|c|}{ ringan } & \multicolumn{2}{|c|}{ sedang } & \multicolumn{2}{|c|}{ berat } & & \\
\hline & f & $\%$ & f & $\%$ & f & $\%$ & f & $\%$ \\
\hline baik & 8 & $\begin{array}{l}28,6 \\
0\end{array}$ & $\begin{array}{l}1 \\
9\end{array}$ & $\begin{array}{l}67, \\
9\end{array}$ & 1 & 3,6 & $\begin{array}{l}2 \\
8 \\
\end{array}$ & $\begin{array}{l}10 \\
0\end{array}$ \\
\hline sedang & 0 & 0 & $\begin{array}{l}3 \\
0\end{array}$ & 75 & $\begin{array}{l}1 \\
0\end{array}$ & 25 & $\begin{array}{l}4 \\
0 \\
\end{array}$ & $\begin{array}{l}10 \\
0\end{array}$ \\
\hline buruk & 0 & 0 & 0 & 0 & 2 & 100 & 2 & $\begin{array}{l}10 \\
0\end{array}$ \\
\hline jumlah & 8 & $\begin{array}{l}11,4 \\
0\end{array}$ & $\begin{array}{l}4 \\
9 \\
\end{array}$ & 70 & $\begin{array}{l}1 \\
3 \\
\end{array}$ & $\begin{array}{l}18, \\
6\end{array}$ & $\begin{array}{l}7 \\
\mathbf{0} \\
\end{array}$ & $\begin{array}{l}10 \\
0 \\
\end{array}$ \\
\hline
\end{tabular}

Berdasarkan tabel 1 dapat diketahui hasil analisis hubungan antara tingkat kebersihan gigi dan mulut dengan status gingivitis pada ibu hamil yang berkunjung ke Poliklinik KIA Puskesmas Andalas. Didapatkan sebagian besar yaitu 3 dari 4 ibu (75\%) yang mempunyai tingkat kebersihan mulut sedang mengalami gingivitis sedang, sisanya $(25 \%)$ mengalami gingivitis berat. Sebagian kecil ibu hamil mempunyai kebersihan mulut yang buruk yaitu sebanyak $2 \mathrm{ibu}$ dan keduanya mengalami gingivitis berat. Sementara itu didapatkan 28 ibu dengan tingkat kebersihan mulut yang baik juga mengalami gingivitis, $8 \mathrm{ibu}$ diantaranya (28,60\%) mengalami gingivitis ringan, $19 \mathrm{ibu}(67,9 \%)$ mengalami gingivitis sedang dan 1 ibu $(3,6 \%)$ mengalami gingivitis berat.

Penelitian ini tidak dapat dilakukan uji statistik karena ada beberapa cell yang bernilai nol. Adanya cell yang bernilai nol tersebut dikarenakan dari hasil penelitian yang mendapatkan tidak adanya ibu dengan tingkat kebersihan mulut yang sedang mengalami gingivitis ringan dan ibu yang mempunyai tingkat kebersihan mulut buruk mengalami gingivitis ringan dan sedang.

\section{PEMBAHASAN}

Hubungan Tingkat Kebersihan Gigi dan Mulut dengan Status Gingivitis pada Ibu Hamil

Hubungan antara tingkat kebersihan gigi dan mulut dengan status gingivitis pada ibu hamil yang berkunjung ke Poliklinik KIA Puskesmas Andalas didapatkan sebagian besar yaitu 3 dari 4 ibu (75\%) mempunyai tingkat kebersihan mulut sedang mengalami gingivitis sedang, sisanya $(25 \%)$ mengalami gingivitis berat. Penelitian ini sejalan dengan penelitian yang dilakukan oleh Hartati dkk (2011) yang mendapatkan ibu hamil dengan plak pada giginya lebih banyak mengalami gingivitis dibanding ibu dengan tidak ada plak pada giginya. (7) 
Hal ini sejalan dengan kepusta- baik juga mengalami gingivitis, 8 ibu kaan yang menyatakan kehamilan itu diantaranya $(28,60 \%)$ mengalami sendiri tidak dapat menyebabkan gingivitis ringan, $19 \mathrm{ibu}(67,9 \%)$ gingivitis. Gingivitis pada kehamilan mengalami gingivitis sedang dan $1 \mathrm{ibu}$ disebabkan oleh bakteri plak, sama $(3,6 \%)$ mengalami gingivitis berat. halnya dengan gingivitis pada wanita Hasil penelitian ini sejalan dengan yang tidak hamil. ${ }^{(12)}$ Plak dan kalkulus kepustakaan yang menyatakan kehamerupakan indikator kebersihan mulut milan dapat meningkatkan respon yang buruk. ${ }^{(13)}$ Seperti yang dilaporkan pada penelitian yang dilakukan oleh Naumah I dan Annan BD (1998) yang mempelajari masalah periodontal dan praktek kebersihan mulut antara wanita hamil dengan yang tidak hamil, melaporkan prevalensi perdarahan gingiva $89 \%$ terjadi pada wanita hamil. Pada tahun 2005 dengan peneliti yang sama, Naumah I dan Annan BD melakukan penelitian di Ghana, hanya mendapatkan $1 \%$ prevalensi perdarahan gingiva. Terlepas dari masalah perubahan hormonal selama kehamilan, ada dan lamanya tingkat plak dan iritasi lokal lainnya merupakan hal yang lebih penting dalam menentukan tingkat keparahan perdarahan gingiva. ${ }^{(14)}$

Sebagian kecil ibu hamil pada penelitian ini mempunyai kebersihan mulut yang buruk yaitu sebanyak $2 \mathrm{ibu}$ dan keduanya mengalami gingivitis berat. Hasil penelitian ini sejalan dengan penelitian yang dilakukan Ganesh (2011) yang mendapatkan secara statistik terdapat hubungan yang bermakna antara tingkat kebersihan mulut (skor OHIS) dengan status gingivitis (skor Indeks Gingiva), dimana tersirat jika terjadi peningkatan skor OHIS, maka juga terjadi peningkatan pada skor Indeks Gingivanya. ${ }^{(14)}$ Hal ini juga sejalan dengan penelitian yang dilakukan oleh Wardhani (2012), dimana semakin buruk tingkat kebersihan mulut ibu hamil maka status gingivanya juga semakin buruk. ${ }^{(10)}$ gingiva terhadap plak dan memodifikasi gambaran klinisnya. ${ }^{(12)}$ Hasil ini juga sejalan dengan kepustakaan yang menyatakan gingivitis yang terjadi pada masa kehamilan lebih berpotensi terjadi pada wanita hamil dengan kebersihan mulut yang buruk dan/atau telah memiliki masalah pada gingiva sebelum kehamilan. Tetapi gingivitis kehamilan juga dapat terjadi pada wanita yang memiliki kebersihan mulut baik dan gusi yang sehat. ${ }^{(9)}$

Selain itu, hasil penelitian ini juga sejalan dengan kepustakaan yang menyatakan selama kehamilan terjadi peningkatan level estrogen dan progesteron yang dapat menyebabkan dilatasi vaskuler gingiva, terjadi statis sirkulasi dan peningkatan kerentanan terhadap iritasi mekanis sehingga menyebabkan jaringan gingiva merespon secara berlebihan terhadap faktor iritasi local. ${ }^{(15)}$ Seperti penelitian yang dilakukan oleh Wardhani (2012), mendapatkan tingkat kebersihan mulut ibu hamil pada semua trimester sebagian besar adalah sedang, dimana pada trimester 1 sebagian besar ibu hamil mengalami gingivitis ringan, sedangkan pada trimester 2 dan 3 sebagian besar mengalami gingivitis sedang. ${ }^{(10)}$ Hal ini terjadi karena selama trimester ketiga kadar estrogen dan progesteron paling tinggi. ${ }^{12}$

Peningkatan level hormon estrogen dan progesteron juga dapat meningkatkan persentase bakteri P.intermedia, karena hormon tersebut Sementara itu didapatkan $28 \mathrm{ibu}$ digunakan oleh bakteri P.intermedia dengan tingkat kebersihan mulut yang sebagai substansi menadione (vitamin 
K) yang dibutuhkan untuk perkembangbiakannya. ${ }^{(15)}$ Bakteri P.intermedia merupakan bakteri patogen penyakit periodontal. ${ }^{(16)} \quad$ Sementara itu, perubahan respon imun maternal selama kehamilan yang mengakibatkan tertekannya respon limfosit $\mathrm{T}$ maternal juga dapat mempengaruhi respon jaringan gingiva terhadap plak. ${ }^{(15)}$

Selain itu, selama kehamilan juga terjadi perubahan komposisi pada plak subgingiva. Seperti yang disebutkan oleh Kornman dan Loesche, selama kehamilan pada trisemester kedua terjadi peningkatan terjadinya gingivitis dan perdarahan gingiva, tanpa terjadi peningkatan kadar plak. Hal ini disebabkan karena selama kehamilan rasio perbandingan bakteri anaerob lebih meningkat dibanding bakteri aerob, khususnya Bacteroides melaninogenenicus dan Provotella intermedia. ${ }^{(12)}$

Hasil penelitian ini tidak dapat dapat dilakukan uji statistik karena ada beberapa cell yang bernilai nol. Adanya cell yang bernilai nol tersebut dikarenakan dari hasil penelitian yang mendapatkan tidak adanya ibu dengan tingkat kebersihan mulut yang sedang mengalami gingivitis ringan dan ibu yang mempunyai tingkat kebersihan mulut buruk mengalami gingivitis ringan dan sedang. Gingivitis terjadi pada semua ibu hamil yang diperiksa. Gingivitis selama kehamilan sudah dapat terjadi pada ibu yang mempunyai tingkat kebersihan mulut baik, dengan tingkat keparahan yang berbeda, yang dapat dipengaruhi oleh tingkat kebersihan gigi dan mulut ibu hamil itu sendiri. Semakin buruk tingkat kebersihan gigi dan mulut ibu, semakin berat tingkat keparahan gingivitisnya.

Penelitian ini sejalan dengan penelitian yang dilakukan Rintoko (2005) yang menyatakan tingkat kebersihan mulut mempengaruhi adanya gingivitis pada ibu hamil. ${ }^{(11)}$ Penelitian ini juga sejalan dengan penelitian yang dilakukan Wardhani (2012) yang mendapatkan adanya hubungan antara tingkat kebersihan mulut dengan status gingiva, dimana semakin buruk tingkat kebersihan mulut ibu hamil, semakin buruk juga status gingivanya. ${ }^{(10)}$

Penelitian ini juga sejalan dengan teori yang ada, bahwa gingivitis kehamilan disebabkan oleh bakteri yang terdapat dalam plak, sama seperti penyebab gingivitis pada wanita yang tidak hamil. Kehamilan meningkatkan respon gingival terhadap plak dan memodifikasi gambaran klinisnya. Tidak ada perubahan yang dapat terjadi pada gingiva selama kehamilan tanpa keterlibatan faktor local. ${ }^{(12,15)}$

\section{KESIMPULAN DAN SARAN}

\section{Kesimpulan}

1. Tingkat kebersihan gigi dan mulut ibu hamil di wilayah kerja Puskesmas Andalas Kecamatan Padang Timur sebagian besar adalah sedang dan sebagian besar juga ibu hamil yang diperiksa mengalami gingivitis sedang.

2. Semua ibu hamil yang diperiksa mengalami gingivitis, baik itu ibu dengan tingkat kebersihan mulut yang baik, sedang maupun buruk.

3. Gingivitis selama kehamilan sudah dapat terjadi pada ibu yang mempunyai tingkat kebersihan mulut baik, dengan tingkat keparahan yang berbeda, yang dapat dipengaruhi oleh tingkat kebersihan mulut ibu hamil itu sendiri. Semakin buruk tingkat kebersihan gigi dan 
mulut ibu, semakin berat tingkat keparahan gingvitisnya.

\section{Saran}

1. Bagi Institusi Pelayanan (Puskesmas) diharapkan lebih meningkatkan kesehatan gigi dan mulut ibu hamil dengan memberikan penyuluhan tentang pentingnya menjaga kesehatan dan kebersihan mulut selama kehamilan, memberi motivasi dan nasehat kepada ibu hamil untuk memeriksakan kesehatan rongga mulutnya ke dokter gigi bersamaan pada saat pemeriksaan kehamilannya (K1K4).

2. Bagi Populasi Penelitian untuk lebih meningkatkan kesadaran agar selalu menjaga kebersihan dan kesehatan gigi dan mulutnya.

3. Bagi Peneliti Lain, disarankan untuk melakukan penelitian lebih lanjut mengenai faktorfaktor lain yang berhubungan dengan kejadian gingivitis yang dapat terjadi selama kehamilan seperti faktor plak dan faktor usia kehamilan. Karena dalam penelitian ini hanya membahas satu faktor yaitu faktor tingkat kebersihan mulut.

\section{KEPUSTAKAAN}

1. Cawson, Scully. 2006. Medical Problem in Dentistry. 5th ed. Australia: Elsevier.

2. Hasibuan, Sayuti. 2010. Perawatan dan pemeliharaan kesehatan gigi dan mulut pada masa kehamilan. Dentika dental journal. Vol 15: 125-129.

3. Diana, Dewi. 2009. Pengetahuan, sikap dan prilaku wanita hamil pengunjung poliklinik obstetry dan ginekologi (obgyn) rsu dr.pringadi medan terhadap kesehatan gigi dan mulut selama masa kehamilan. Skripsi Kedokteran Gigi. Medan: Fakultas Kedokteran Gigi Universitas Sumatera Utara.

4. Willmann, D.E., \& NieldGehrig, J.S. 2008. Foundation of Periodontics for the Dental Hygienist. Philadelphia: Lippicont Williams \& Wilkins.

5. Retnoningrum, D. 2006. Gingivitis pada ibu hamil sebagai faktor resiko terjadnya bayi berat badan lahir rendah kurang bulan di rs. Kariadi Semarang. Dentika dental journal. Vol 1: 1-8.

6. Neville, B.W., Damm, D.D., \& White, D.K. 2003. Color atlas of clinical oral pathology. $2^{\text {nd }}$ ed. USA: Medical Book.

7. Hartati, et al. 2011. Analisis faktor-faktor yang berhubungan dengan kejadian gingivitis pada ibu hamil di wilayah kerja puskesmas talang tegal. Jurnal ilmiah kesehatan keperawatan. Vol 7 No 3: 170-189.

8. Novianto. 2010. Manajemen kesehatan gigi pada kehamilan. Skripsi Kedokteran. Solo: Universitas Negeri Solo.

9. Felton, Ann. 2009. Basic guide to oral health education and promotion. United Kingdom: Wiley-Blackwell.

10. Wardhani, Dika Fitria. 2012. Hubungan tingkat kebersihan 
rongga mulut dengan status gingiva pada ibu hamil di wilayah kerja puskesmas sumber sari kecamatan sumbersari kabupaten jember (penelitian observasional klinis). Skripsi Kedokteran Gigi. Jember : Universitas Jember.

11. Rintoko, Bimo. 2005. Kebersihan mempengaruhi adanya gingivitis pada ibu hamil. Dentika dental journal. Vol 1: 1-9.

12. Newman, A. 2006. Carranza's clinical periodontology. $10^{\text {th }} \mathrm{ed}$. Philadelphia: WB.Saunders company.

13. Sriyono, N.W., \& Sudibyo. 2011. Ilmu kesehatan oral. Yogyakarta: Fakultas Kedokteran dan Ilmu Kesehatan Universitas Muhammadiyah.
14. Ganesh, Akila, et al. 2011. A survey on dental knowledge and gingival health of pregnant women attending government maternity hospital, Chennai. Journal of Oral Health \& Community Dentistry. 5(1): 2430.

15. Daliemunthe, S.H. 2008. Periodonsia. Medan: Departemen Periodonsia FKG USU.

16. Lindhe, 2008. Clinical Periodontology and Implant Dentistry. $5^{\text {th }}$ ed. United Kingdom: Wiley-Blackwe. 